\title{
The Influence of Learning Models and Initial Ability Students on Material Science Process Skills Light and Properties of Class IV Students SD State 094099 Siruberube
}

\author{
Junanshe Nando Sinaga ${ }^{1, *}$ Hasruddin $^{2}$ Ramlan Silaban ${ }^{2}$ \\ ${ }^{1}$ Postgraduate Student at Medan State University, Indonesia \\ ${ }^{2}$ Postgraduate Lecturer at the State University of Medan, Indonesia \\ *Corresponding author. Email: sinagaando84@gmail.com
}

\begin{abstract}
The purpose of this study was to determine: (1) The differences in science process skills of students who were taught using guided inquiry learning models using discovery learning models, (2) The interaction between learning models and students 'initial abilities in influencing students' science process skills. This research is a quasi-experiment. The study population was all fourth grade students of SD Negeri 094099 Siruberube which consisted of 2 classes. From the two fourth grade students, the experimental class was chosen to be treated with guided inquiry learning and the control class was given discovery learning treatment. The instrument to measure science process skills used essay tests. The data analysis technique used ANOVA at the significance level $\alpha=0.05$. The results showed: (1) There were differences in the science process skills of students using the guided ingkuiri learning model using the discovery learning model. The science process skills of students using the guided inquiry learning model with an average score of 73.04, while the science process skills of students using the discovery learning model obtained an average score of 60.67, (2) There is an interaction between the learning model and the initial ability to process skills. student science. Based on the results of the ANAVA test, the value of sig $=0.036$ <sig.0.05, thus proving the interaction between learning models and students 'initial abilities in influencing students' science process skills.
\end{abstract}

Keywords: Guided Inquiry Model, Discovery, and Science Process Skills

\section{INTRODUCTION}

Learning is not only aimed at mastering the material, but must emphasize the process and make students active during learning through a series of activities so that learning is meaningful for students. This is in accordance with Sedarmayanti's opinion (2001:32) This is in accordance with the opinion that through education a person is prepared to have the provisions to be ready to know, recognize and develop methods of thinking systematically by demanding student activities in the classroom through problems that are solved by students themselves, so that they are useful for students in facing the future.

Wijanarko (2017:121) emphasized that science learning should place more emphasis on science process skills that are able to engage students actively and creatively through the learning experiences carried out. Next Rustaman (2010:80) said states that science process skills include activities in making observations, interpreting observations, classifying, communicating, predicting, and formulating hypotheses to drawing conclusions. Thus it can be understood that science learning certainly emphasizes students' science process skills which encourage students to always be active in the implementation of learning in class.

Varadela (2017:84) and Annisa (2017:110) emphasized that science process skills in the field of science have a positive impact on understanding a learning concept because science process skills affect the ongoing learning process, which makes it easier for students to understand a learning material. It is certainly understandable that the science process skills possessed by students will be able to support students' abilities in 
understanding and mastering the given science subject matter. Erina and Kuswanto (2015:203) emphasizes that science process skills are applied in learning by providing expansion in the world of education because it can combine learning with a game in it that makes students feel they are not in learning but still find something new as learning, namely through experimental activities or direct experience.

In the observation activities carried out at SD Negeri 094099 Siruberube Dolok Pardamean, Simalungun Regency, it was found that science learning that should be in accordance with educational goals was in fact not implemented properly. Where in teaching and learning activities that take place, the teacher only explains a little material and gives assignments to students, thus making students less understanding of the material, less enthusiastic and working on assignments whose results are also unsatisfactory.

The results of the observations also found that when the learning process took place in class IV, especially in light material and its properties, among others, the ability of students to understand light material and its properties conceptually was still low, this was evidenced by student learning outcomes that were not in accordance with the minimum completeness criteria. which is determined by the school with a value of 70 . The application of learning to develop skills is still lacking, especially in science process skills so that students' science process skills in the learning process of light material and its properties are classified as low.

\section{THEORETICAL REVIEW}

Suyono dan Hariyanto (2015:9) states that learning is an activity carried out in obtaining knowledge, increasing abilities, and also improving behavior. In line with this opinion, Djamarah dan Zain (2013:13) said that learning is a series of activities that include body and soul to obtain a change in behavior involving cognitive, affective, and psychomotor resulting from individual personal experiences.

The learning model is a way of designing the implementation of learning. Through the learning model, there will be efforts to create a climate and service for the diverse abilities, potentials, interests, talents and needs of students so that interactions occur between teachers and students or between students. In a learning model there are usually stages or syntax for its implementation.

Rusman (2014:133) said that learning model is a pattern that can be used to shape the curriculum, design learning materials, and guide learning in the classroom. According to Komulasari (2010:57), The learning model is a form of learning that is presented by the teacher in a typical way that is illustrated from beginning to end. Another opinion by Suprijono (2010:54) which states the learning model is a conceptual framework in organizing learning experiences to achieve certain learning objectives that describe procedures in a directed manner.

Bilgin (2009:118) said that teaching and learning process during which learners ask their own question, plan their own inquiries, analyze and discuss their findings and construct their own understanding proves learning to be more effective and long lasting.

Based on some of the opinions expressed above, the authors conclude that the guided inquiry model is a learning model that emphasizes students to be more active in learning, where students can find or research problems based on facts to obtain data, while the teacher is only a facilitator and mentor for students in study.

\section{RESEARCH METHODS}

The type of research used is quasi-experimental. The use of this type of research is in a class that has been formed previously and does not make changes to the situation or condition of the existing class. This study used two groups drawn from one population with two separate samples. One sample group was treated using guided inquiry learning and discovery. Furthermore, measurements were taken to determine the students' science process skills.

This study uses data analysis techniques in the form of descriptive analysis and inferential analysis. The descriptive analysis technique is intended to describe the research data including the mean, mode, variance and standard deviation. The data that has been obtained are then presented in the form of a frequency distribution table and a histogram of data trends.

Inferential analysis technique is used to test the research hypothesis by using analysis of variance (ANOVA) technique. Sudjana (2005:211) explain before ANOVA is performed, the analysis requirements are first determined, namely the normality requirements using the Liliefors test, while for the homogeneity test requirements.

\section{RESULT AND DISCUSSION}

Based on the results of processing and analysis of research data, the following research results can be stated. 
Table 1. Anova test results

Tests of Between-Subjects Effects

Dependent Variable:Test Result

\begin{tabular}{|c|c|c|c|c|c|}
\hline Source & $\begin{array}{l}\text { Type III } \\
\text { Sum of } \\
\text { Squares }\end{array}$ & df & $\begin{array}{l}\text { Mean } \\
\text { Square }\end{array}$ & $\mathrm{F}$ & Sig. \\
\hline $\begin{array}{l}\text { Corrected } \\
\text { Model }\end{array}$ & $5231.345^{\mathrm{a}}$ & 5 & 1046.269 & 42.507 & .000 \\
\hline \multirow[t]{2}{*}{ Intercept } & 158636.375 & 1 & 158636.375 & 6.44553 & .000 \\
\hline & 1063.776 & 1 & 1063.776 & 43.218 & .000 \\
\hline $\begin{array}{l}\text { Early } \\
\text { ability }\end{array}$ & 2822.413 & 2 & 1411.207 & 57.334 & .000 \\
\hline $\begin{array}{l}\text { Models * } \\
\text { early } \\
\text { ability }\end{array}$ & 175.181 & 2 & 87.590 & 3.559 & .036 \\
\hline Error & 1181.470 & 48 & 24.614 & & \\
\hline Total & 247748.000 & 54 & & & \\
\hline $\begin{array}{l}\text { Corrected } \\
\text { Total }\end{array}$ & 6412.815 & 53 & & & \\
\hline
\end{tabular}

a. $\mathrm{R}$ Squared $=, 816$ (Adjusted R Squared $=$ ,797)

Based on the results of the Anova test above, the calculated value of $\operatorname{sig}=0.000$ is smaller than $\operatorname{sig}=0.05$, which means that $\mathrm{H} 0$ ᄀ is rejected so that it can be concluded that there are differences in the science process skills of students who are taught using guided inquiry learning models and discovery learning models on students' science process skills.

Based on the results of the Anova test above, the calculated value of sig $=0.000$ is smaller than sig $=0.05$, which means that $\mathrm{HO} \neg$ is rejected, so it can be concluded that there is an effect of initial ability on science process skills taught using guided inquiry learning models and discovery learning models.

Based on the results of the Anova test above, the calculated value of $\operatorname{sig}=0.000$ is smaller than the provision of the price, sig $=0.05$, which means that $\mathrm{H} 0$ is rejected. So the category of Students' Initial Ability has an effect on students' science process skills. The results of the calculation of learning interactions and students' initial abilities are sig $=0.036$, smaller than sig $=0.05$, $(0.036<0.05)$, it can be concluded that reject $\mathrm{HO}$ and accept $\mathrm{Ha}$, which means there is an interaction between the learning model and Initial Ability towards students' science process skills.

The results of the calculation and analysis of the science process skills of students who were taught with the guided inquiry learning model were higher or better than the science process skills of students who were taught with the discovery learning model. Students who take lessons with guided inquiry learning models are accustomed to being active in solving thinking problems individually to get concepts. Because the learning process is not just transferring knowledge from the teacher to students, but a process that is conditioned or pursued by the teacher, so that students are active in various ways to build their own knowledge.

The results of the above analysis confirm the importance of student motivation and facilitation by the teacher. In order for children's intellectual development to take place optimally, they need to be motivated and facilitated to build theories that explain the world around them. In the guided inquiry learning model, teachers are required to facilitate and encourage students to be actively involved in the learning process so that they are able to construct knowledge for themselves.

Based on the results of data analysis after the classroom learning that was taught with the guided inquiry learning model and the class taught with the discovery learning model, the post-test scores for science process skills in both classes were obtained. The average post-test score of students' science process skills taught by the guided inquiry learning model was 73.037 and the average score of students' science process skills to students taught by the discovery learning model was 60.667 .

The results of Anova's calculation of the post-test scores of the guided inquiry learning model group and the discovery learning model obtained a learning sig arithmetic value of 0.000 with the provisions of $\mathrm{sig}=$ 0.05 . Because the value of $\operatorname{sig}<\mathrm{Sig}=0.05$ means $\mathrm{H} 0 \neg$ is rejected, so it can be concluded that there are differences in science process skills using the guided inquiry learning model and students' science process skills using discovery learning models.

The results of the data analysis above prove the importance of science process skills for students. Zulfiani (2009:51) emphasizes that science process skills are skills that scientists usually do to acquire knowledge. By using process skills, students will be able to discover and develop their own facts and concepts.

In accordance with the characteristics of science, especially science learning with light material and its properties, it is certainly supported by a guided inquiry learning model, which is related to how to find out systematically, not only facts, concepts, principles but emphasizes discovery. Students' ability to find concepts needs to be equipped with scientific learning activities. The training of students in using these process skills will make it easier for them to apply scientific concepts in everyday life, including in students' understanding of light material and its properties.

One science process skill has a relationship with other process skills. The use of one process skill will affect the development of other process skills. Each of the mutual process skills possessed by students will certainly support the ability of students to understand and master the material both conceptually and in fact, especially in the subject matter of light and its properties. 
The results of this study are also in line with several previous studies, namely research by Ambarsari et al (2013) who reported through the Journal of Biology Education entitled Application of Guided Inquiry Learning to Basic Science Process Skills in Biology Lessons for Class VIII Students. The results showed that the application of guided inquiry learning had a significant effect on the basic science process skills of eighth grade students of SMP Negeri 7 Surakarta.

Aktamis and Ergin (2008) said that the effect of learning science process skills on students' scientific creativity, scientific behavior, and learning outcomes shows a significant difference compared to students who learn with conventional learning. Students who get learning with science process skills show better learning outcomes than those taught by traditional learning. The average attitude ability does not show a significant difference with conventionally taught classes on the grounds that the application time is quite short.

Research Setiowati et al (2015) through the Journal of Chemistry Education entitled Application of Guided Inquiry Learning Model Equipped with Worksheets to Improve Student Activities and Learning Achievement on Main Material Solubility and Solubility Product Class XI MIA SMA Negeri 1 Banyudono 2014/2015 Academic Year conveyed that the application of the guided inquiry learning model equipped with worksheets can increase students' learning activities on the material solubility and solubility product (the achievement of learning activities in the first cycle was $52 \%$ increased to $80 \%$ in the second cycle). The guided inquiry model is effective in helping teachers motivate students to ask questions which is an important part of inquiry-based learning.

The research of Smith et al. (2007) reported in the Proquest Education Journal entitled Inquiry-Oriented Instruction in Science: Who Teach That Way? that guided inquiry shows learning activities that make students active including observing, asking questions, gathering other necessary information, planning research, using equipment to collect data, analyzing and interpreting data, providing answers, and communicating the results. From these activities, students' ability to perform science skills will further develop.

\section{CONCLUSION}

Based on the results of the analysis, findings and discussions that have been presented in the previous chapter, several conclusions were obtained relating to the guided inquiry learning model and discovery learning model, and science process skills. The conclusions are stated as follows:

1. There are differences in students' science process skills using the guided inquiry learning model with students' science process skills using the discovery learning model. The students' science process skills using the guided inquiry learning model with an average value of 73.04 , while the students' science process skills using the discovery learning model get an average score of 60.67 .

2. There is an interaction between the learning model and the initial ability of students' science process skills. Based on the results of the ANOVA test, the value of sig $=0.036<$ sig. 0.05 was obtained, thus proving the interaction between the learning model and students' initial abilities in influencing students' science process skills.

\section{REFERENCES}

[1] Aktamis, H. \& Ergin, O. (2008). The Effect of Scientific Process Skills Education on Student's Scientific Creativity, Science Attitudes and Academic Achievements. Jurnal Science Learning and Teaching. 9 (1) : 1-21.

[2] Ambarsari, W., Santosa, S dan Maridi. (2013). Penerapan Pembelajaran Inkuiri Terbimbing Terhadap Keterampilan Proses Sains Dasar Pada Pelajaran Biologi Siswa Kelas VIII SMP Negeri 7 Surakarta, Jurnal Pendidikan Biologi. 5 (1): 81-95.

[3] Annisa, K., Saptorini., dan Sumarni, W. (2017). Keefektifan Pendekatan Process Oriented Guided Inquiry Learning Terhadap Keterampilan Proses Sains. Jurnal Chemistry in Education. 6 (1): 40 - 46.

[4] Bilgin, I. (2009). The Effect of Guided Inquiry Instruction Incorporating a Cooperative Learning Approachon University student's Achievement of Acid and Based Concept and Attitude Toward Guided Inquiry Instruction. Scientific Research and Essay. 4 (10): 1038-1046.

[5] Djamarah dan Zain. (2013). Strategi Belajar Mengajar. Jakarta: Rineka Cipta.

[6] Erina, R dan Kuswanto, H. (2015). Pengaruh Model Pembelajaran InsTAD Terhadap Keterampilan Proses Sains dan Hasil Belajar Kognitif Fisika di SMA. Jurnal Inovasi Pendidikan IPA. 1 (2): 202 211.

[7] Komulasari. (2010). Pembelajaran Kontekstual Konsep dan Aplikasi. Bandung: Refika Aditama.

[8] Rusman. (2014). Model-Model Pembelajaran. Jakarta: Raja Grafindo Persada.

[9] Rustaman, N. (2010). Assesmen dalam Pembelajaran Sains. Bandung: Program Doktor Pendidikan IPA Sekolah Pascasarjana UPI.

[10] Sedarmayanti. (2001). Sumber Daya Manusia dan Produktivitas Kerja. Jakarta: Mandar Maju. 
[11] Setiowati, H., Agung, NCS., dan Widiastuti, AES. (2015). Penerapan Model Pembelajaran Inkuiri Terbimbing (Guided Inquiry) Dilengkapi LKS Untuk Meningkatkan Aktivitas Dan Prestasi Belajar Siswa Pada Materi Pokok Kelarutan Dan Hasil Kali Kelarutan Kelas XI MIA SMA Negeri 1 Banyudono Tahun Pelajaran 2014/2015. Jurnal pendidikan Kimia. 4(4) : 54-60.

[12] Smith, TM., Desimone LM., Zeidner, TL., Dunn, AC., Bhatt, M., dan Rumyantseva, NL. (2007). Proquest Education Journal berjudul InquiryOriented Instruction in Science: Who Teach That Way? Journal Educational Evaluation and Policy Analysis. 29 (3): 88-97.

[13] Sudjana. (2005). Metode Statistika.. Bandung: PT. Tarsito.

[14] Suprijono. (2010). Cooperative Learning Teori \& Aplikasinya. Yogyakarta: Pustaka Pelajar.

[15] Suyono dan Hariyanto. (2015). Implementasi Belajar \& Pembelajaran. Bandung: Remaja Rosdakarya.

[16] Varadela, A., Saptorini \& Endang. (2017). Pengaruh Praktikum Berbasis Inkuiri Terbimbing Berbantuan Lembar Kerja Praktikum terhadap Keterampilan Proses Sains. Jurnal Chemistry in Education. 6 (1): $33-39$.

[17] Wijanarko, AG., Supardi, KI., dan Marwoto, P. (2017). Keefektifan Model Project Based Learning Terbimbing Untuk Meningkatkan Keterampilan Proses Sains dan Hasil Belajar IPA. Journal of Primary Education. 6 (2): 120-125.

[18] Zulfiani. (2009). Strategi Pembelajaran Sains. Jakarta: Lembaga Penelitian UIN Jakarta. 